\title{
Can Parenting Styles and Dimensions Questionnaire (PSDQ) Be Used in China?* $^{*}$
}

\author{
Yixiao $\mathrm{Fu}^{1}$, Xiao $\mathrm{Hou}^{2}$, Qing Qin ${ }^{1}$, Huaqing Meng ${ }^{1 \#}$, Peng Xie ${ }^{3 \#}$, Yi Huang ${ }^{4}$, \\ Xiaohong $\mathrm{Ma}^{4}$, Wei Deng ${ }^{4}$, Qinghua $\mathrm{Luo}^{1}$, Yingcheng Wang ${ }^{4}$, Hua $\mathrm{Hu}^{1}$, Lian $\mathrm{Du}^{1}$, \\ Haitang Qiu ${ }^{1}$, Tian Qiu ${ }^{1}$, Tao $\mathrm{Li}^{4 \#}$ \\ ${ }^{1}$ Mental Health Center, The First Affiliated Hospital of Chongqing Medical University, Chongqing, China \\ ${ }^{2}$ Chongqing Medical and Pharmaceutical College, Chongqing, China \\ ${ }^{3}$ Department of neurology, The First Affiliated Hospital of Chongqing Medical University, Chongqing, China \\ ${ }^{4}$ Mental Health Center, West China Hospital, Sichuan University, Chengdu, China \\ Email: ${ }^{*}$ mhq99666@sina.com, ${ }^{*}$ xiepeng@ecquu.edu.cn, ${ }^{*}$ xuntao26@ hotmail.com
}

Received January $26^{\text {th }}, 2013$; revised February $27^{\text {th }}, 2013$; accepted March $26^{\text {th }}, 2013$

Copyright (C) 2013 Yixiao Fu et al. This is an open access article distributed under the Creative Commons Attribution License, which permits unrestricted use, distribution, and reproduction in any medium, provided the original work is properly cited.

\begin{abstract}
Objective: To evaluate the validity and reliability of the Chinese version of PSDQ (Parenting Styles and Dimensions Questionnaire, PSDQ). Method: 443 parents of children aged 6 to 16 who lived in Chongqing were selected. .52 of them were retested 6 weeks later in order to assess the retest reliability. Determination of reliability included: internal consistency: to calculate Cronbach coefficient; coefficient of retest reliability: to calculate person correlation of results in every subscale in twice measurements of 52 parents. Determination of validity: content validity, structural validity, confirmatory factor analysis. Results: For each subscale and factor, the values of kappa for inter-rater reliability were between .625 and .884 ( $p$ $<.05)$; the values of retest reliability were between .537 and $.832(p<.05)$; The scores of the subscale of PSDQ were correlated with each factor significantly (coefficient of correlation: .732 - .951, $p<.05$ ), and the correlation coefficient was more than those between each factor of this subscale (correlation coefficient: $.382-.834, p<.05$ ). The confirmatory factor analysis of PSDQ showed the result met the criteria standard for adequacy of fit. (CMIN/df: 2.218 - 3.745; TLI: .808 - .920; RMSEA: .052 - .079; MECVI of default model was very close to that of saturated model, most of proliferation index were more than .8). Conclusion: Parenting Style and Dimensions Questionnaire (PSDQ), in line with requirements of psychometric, had good reliability and validity and was useful as a tool to evaluate the parenting styles for parents.
\end{abstract}

Keywords: Parenting Style; Parenting Styles and Dimensions Questionnaire; Reliability; Validity

\section{Introduction}

During the period of children's growth and development, the parents are the children's first teachers. Parents' attitude to the children, manners and behaviors directly affect the children's personality and temperament shaping as well as mental health development, which has been paid extensive attention from related fields such as education and medicine, but domestic researches focusing on parenting styles and the adolescents (Wang \& Yuan, 2008; Bi, Wang, Yang, \& Wang, 2007) personality, psychology, emotion and behavior are few. However, most information on parenting styles is obtained from Egma Minnen av Bardndosnauppforstran (EMBU) (Yue, Li, Jin, \& Ding, 1993) whose respondent is children (object's evaluation), thus, the basis of parenting intervention theory is weak because the information is obtained indirectly. Besides, the respondents are small to be biased to their parents' evaluation because the scale is suitable for the respondents who are over 14 years old and can understand the questions. The restriction on the re-

\footnotetext{
*Grant from the National Natural Science Foundation of China (81101025).
}

\#Corresponding authors. spondents' age results in more researches on the middle school students and college students' parents' parenting and their mental issues, personality and socialization, but few researches on young children's family environment. However, an individual's personality development and mental development are directly related to the parents' early parenting, so local version of the parenting scale (Xia \& Liu, 2004) is intended to develop, but it is not widely applied because of the scale itself. In addition, the research on family environment also needs be in line with internationalization, therefore, it is necessary to introduce mature and comprehensive parenting scale with the parents themselves as the respondents.

Parenting Style \& Dimensions Questionnaire was developed by Robinson and Mandleco in 1995, which was internationally recognized as one of the scales with the parents as the respondents to evaluate the parenting style. Since it is developed, the scale has been revised and used by scholars all over the world and is demonstrated to have good reliability and validity (Robinson, Mandleco, \& Olsen, 2001). Therefore, this research aims to translate the scale into Chinese and measure its reliability and validity to hope to provide an effective assessment tool to 
measure Chinese children's family environment.

\section{Objective and Methods}

\section{Objective}

Method of cluster sampling was used to select 443 parents of 6 - 16 years old children who were full-time students in key primary school, key middle school, ordinary primary school, ordinary middle school and occupation high school in main city zone of Chongqing during the period of February to June, 2008.

Inclusion standard: mother (or father) whose child was 6 - 16 years old and student accepted education for all the people and could fully understand the content of scale. Exclusion standard: mother (or father) who could not participate in the test because of physical diseases and mental illnesses.

This study was approved by Ethics Committee of Chongqing Medical University and the parents participated in the survey after they signed written informed consent.

\section{Methods}

\section{Introduction and Translation of the Scale}

Parenting Style and Dimensions Questionnaire, with 62 items evaluated using 5 points, was used for father or mother to evaluate his or her and spouse/partner's attitude to frequency of children's some behaviors, aiming to mainly understand the parenting styles. 3 parenting styles, authoritative parenting, authoritarian parenting and permissive parenting were further divided into 11 factors (dimensions). Authoritative parenting included 27 items which were divided into 4 factors: passion and concentration, rationality/guidance, democratic participation and good nature/kindness. Authoritarian parenting included 20 items which were divided into 4 factors: verbal confrontation, corporal punishment, irrationality/or punitive strategy and command. Permissive parenting included 15 items (among of which, 3 items with reverse scoring) which were divided into 3 factors: no persistence, ignorance of inappropriate behaviors and lack of confidence. The approach of translation and backtranslation procedure were used to compare the Chinese vision of scale and the original scale. The scale was formally used until the version of back-transition was basically close to the original scale.

\section{Formal Test with Chinese Version of Parenting Style and Dimensions Questionnaire}

The method of cluster sampling was used to select 70 parents from ordinary primary school, key primary school, ordinary middle school and key middle school respectively and 120 parents from occupation high school as the subjects. The scale was given out to the students by the teacher in charge of the class and then brought home by the students. The scale was filled out by the students' father or mother (For the parents, there were written detailed instructions and informed consent as well as an envelope which could be returned back according to the parent's willing). Within two days, the answer sheets were recycled and the invalid questionnaires were cancelled. 6 weeks later, 60 subjects were retested and 52 valid questionnaires were obtained.

Validity and Reliability Assessment of Chinese Version of Parenting Style and Dimensions Questionnaire

Reliability test included homogeneity reliability: calculating the Cronbach coefficient of the total scale and subscales; test-retest reliability: calculating the Spearson correlation coefficient of 52 students' parents' scores of each subscale 6 weeks before and after. Validity test was to calculate the Spearson correlation coefficient between each subscale and each factor as well as Spearson correlation coefficient between factors. Confirmatory factor analysis was to analyze the content validity and construct validity of the scale.

\section{Statistical Method}

Paired t-test was used to evaluate the test-retest reliability and Cronbacha coefficient was used to estimate internal consistency. Total validity and content validity were analyzed with Pearson correlation. All above were analyzed with SPSS 16.0 and confirmatory factor analysis was analyzed with AMOS7.0.

\section{Results}

\section{General Description of the Data}

443 valid questionnaires were obtained from the students' parents. The distribution of subjects' (parents) children's schools was as follows: 51 students from key primary school (11.5\%), 65 students from ordinary primary school (14.8\%), 56 students from key middle school $(12.6 \%), 57$ students from ordinary middle school $(12.7 \%)$, 60 students from key high school (13.5\%), 53 students from ordinary high school (12\%), 101 students from occupation high school (23\%); the students' average age was $12.37+3.53$ years old; among the parents, fathers accounted for 189 (occupation including: administrative management: $7.5 \%$; business: $13.9 \%$; service industry: $9.7 \%$; professional technology: $17.5 \%$; worker: $10.1 \%$ ) and mothers accounted for 254 (occupation including: administrative management: $6.9 \%$; business: $14.3 \%$; service industry: $9.9 \%$; professional technology: 11.5\%; worker: $15.7 \%$ ).

\section{Reliability Test of Chinese Version of Parenting Style and Dimensions Questionnaire}

Internal reliability (Cronbach $\alpha$ ) of each subscale was between .634 and .783 (internal reliability of each factor of subscales: .626 - .866) and test-retest reliability were between .537 and .832 (test-retest reliability of each factor of subscales: .537 - .832) (see Table 1).

\section{Validity Test of Chinese Version of Parenting Style and Dimensions Questionnaire}

Because there was no quantified tool for parenting style measurement based on Baumrind model, criterion-related validity was not included into reliability indexes in this research and content validity, construct validity and confirmatory factor analysis were analyzed as the evaluation indexes of reliability.

\section{Content Validity}

In authoritative parenting subscale, authoritarian parenting subscale and permissive parenting subscale, the correlation coefficients between each factor and subscale were between .732 and .951 , which was found to be relatively high $(p<.01)$ (see Tables 2-7).

\section{Structure Validity}

The correlations between authoritative parenting subscale, 
Table 1.

Reliability test of authoritative parenting subscale of Chinese version of Parenting Style and Dimensions Questionnaire (PSDQ).

\begin{tabular}{|c|c|c|c|c|c|}
\hline Factors and subscales & Cronbach $\alpha$ & Test-retest reliability & Factors and subscales & $\begin{array}{l}\text { Cronbach } \alpha \\
\text { coefficient }\end{array}$ & Test-retest reliability \\
\hline $\begin{array}{c}\text { Father's score of } \\
\text { authoritative parenting }\end{array}$ & .871 & .665 & $\begin{array}{l}\text { Mother's score of } \\
\text { authoritative parenting }\end{array}$ & .857 & .728 \\
\hline $\begin{array}{l}\text { Father's score of } \\
\text { authoritarian parenting }\end{array}$ & .884 & .698 & $\begin{array}{l}\text { Mother's score of } \\
\text { authoritarian parenting }\end{array}$ & .868 & .783 \\
\hline $\begin{array}{l}\text { Father's score of } \\
\text { permissive parenting }\end{array}$ & .805 & .634 & $\begin{array}{l}\text { Mother's score of } \\
\text { permissive parenting }\end{array}$ & .803 & .728 \\
\hline
\end{tabular}

Table 2.

Correlation matrix of father's authoritative parenting subscale and each factor.

\begin{tabular}{|c|c|c|c|c|c|}
\hline Subscales and factors & $\begin{array}{l}\text { Father's passion and } \\
\text { concentration }\end{array}$ & $\begin{array}{l}\text { Father's rationality and } \\
\text { guidance }\end{array}$ & $\begin{array}{l}\text { Father's democratic } \\
\text { participation }\end{array}$ & $\begin{array}{c}\text { Father's good } \\
\text { nature/kindness }\end{array}$ & $\begin{array}{l}\text { Father's authoritative } \\
\text { parenting subscale }\end{array}$ \\
\hline $\begin{array}{l}\text { Factor 1: Father's passion and } \\
\text { concentration }\end{array}$ & 1 & $.748\left(^{* *}\right)$ & $.793\left(^{* *}\right)$ & $.764\left(^{* *}\right)$ & $.951\left(^{* *}\right)$ \\
\hline $\begin{array}{c}\text { Factor 2: Father's rationality and } \\
\text { guidance }\end{array}$ & $.748\left(^{* *}\right)$ & 1 & $.724\left(^{* *}\right)$ & $.656\left(^{* *}\right)$ & $.880\left(^{* *}\right)$ \\
\hline $\begin{array}{l}\text { Factor 3: Father's democratic } \\
\text { participation }\end{array}$ & $.793\left(^{* *}\right)$ & $.724\left(^{* *}\right)$ & 1 & $.679\left(^{* *}\right)$ & $.885\left(^{(* *}\right)$ \\
\hline $\begin{array}{l}\text { Factor 4: Father's good } \\
\text { nature/kindness }\end{array}$ & $.764\left(^{* *}\right)$ & $.656\left(^{* *}\right)$ & $.679\left(^{* *}\right)$ & 1 & $.838\left(^{* *}\right)$ \\
\hline $\begin{array}{l}\text { Father's authoritative } \\
\text { parenting subscale }\end{array}$ & $.951\left(^{* *}\right)$ & $.880\left(^{* *}\right)$ & $.885\left(^{* *}\right)$ & $.838\left(^{* *}\right)$ & 1 \\
\hline
\end{tabular}

Table 3.

Correlation matrix of mother's authoritative parenting subscale and each factor.

\begin{tabular}{|c|c|c|c|c|c|}
\hline & $\begin{array}{l}\text { Mother's passion and } \\
\text { concentration }\end{array}$ & $\begin{array}{l}\text { Mother's rationality } \\
\text { and guidance }\end{array}$ & $\begin{array}{l}\text { Mother's democratic } \\
\text { participation }\end{array}$ & $\begin{array}{l}\text { Mother's good } \\
\text { nature/kindness }\end{array}$ & $\begin{array}{l}\text { Mother's authoritative } \\
\text { parenting subscale }\end{array}$ \\
\hline $\begin{array}{l}\text { Factor 1: Mother 's passion } \\
\quad \text { and concentration }\end{array}$ & 1 & $.718\left(^{* *}\right)$ & $.745\left(^{* *}\right)$ & $.750\left(^{* *}\right)$ & $.943\left(^{* *}\right)$ \\
\hline $\begin{array}{c}\text { Factor 2: Mother 's rationality } \\
\text { and guidance }\end{array}$ & $.718\left(^{* *}\right)$ & 1 & $.674\left(^{* * *}\right)$ & $.640\left(^{* *}\right)$ & $.866\left(^{* *}\right)$ \\
\hline $\begin{array}{l}\text { Factor 3: Mother 's democratic } \\
\text { participation }\end{array}$ & $.745\left(^{* *}\right)$ & $.674\left(^{* *}\right)$ & 1 & $.635\left(^{* *}\right)$ & $.856\left(^{* *}\right)$ \\
\hline $\begin{array}{l}\text { Factor 4: Mother 's good } \\
\text { nature/kindness }\end{array}$ & $.750\left(^{* *}\right)$ & $.640\left(^{* *}\right)$ & $.635\left(^{* *}\right)$ & 1 & $.829\left(^{* *}\right)$ \\
\hline $\begin{array}{l}\text { Mother's authoritative } \\
\text { parenting subscale }\end{array}$ & $.943\left(^{* *}\right)$ & $.866\left(^{* *}\right)$ & $.856\left(^{* *}\right)$ & $.829\left(^{* *}\right)$ & 1 \\
\hline
\end{tabular}

Table 4.

Correlation matrix of father's authoritarian parenting subscale and each factor.

\begin{tabular}{|c|c|c|c|c|c|}
\hline & $\begin{array}{l}\text { Father's verbal } \\
\text { confrontation }\end{array}$ & $\begin{array}{l}\text { Father's corporal } \\
\text { punishment }\end{array}$ & Father's irrationality & Father's order & $\begin{array}{l}\text { Father's authoritarian } \\
\text { parenting subscale }\end{array}$ \\
\hline $\begin{array}{l}\text { Factor 1: Father's verbal } \\
\quad \text { confrontation }\end{array}$ & 1 & $.717\left(^{* *}\right)$ & $.680\left(^{* *}\right)$ & $.637\left(^{* *}\right)$ & $.842\left(^{* *}\right)$ \\
\hline $\begin{array}{l}\text { Factor 2: Father's } \\
\text { corporal punishment }\end{array}$ & $.717\left(^{* *}\right)$ & 1 & $\left..8322^{* *}\right)$ & $.607\left(^{* *}\right)$ & $.939\left(^{* *}\right)$ \\
\hline Factor 3: Father's irrationality & $.680\left(^{* *}\right)$ & $.832\left(^{* *}\right)$ & 1 & $.566\left(^{* *}\right)$ & $.919\left(^{* *}\right)$ \\
\hline Factor 4: Father's order & $.637\left(^{* *}\right)$ & $.607\left(^{* *}\right)$ & $.566\left(^{* *}\right)$ & 1 & $.752\left(^{* *}\right)$ \\
\hline $\begin{array}{l}\text { Father's authoritarian } \\
\text { parenting subscale }\end{array}$ & $.842\left(^{* *}\right)$ & $.939\left(^{* *}\right)$ & $\left..919^{* *}\right)$ & $.752\left(^{* *}\right)$ & 1 \\
\hline
\end{tabular}


Table 5.

Correlation matrix of mother's authoritarian parenting subscale and each factor.

\begin{tabular}{|c|c|c|c|c|c|}
\hline & $\begin{array}{l}\text { Mother's verbal } \\
\text { confrontation }\end{array}$ & $\begin{array}{l}\text { Mother's corporal } \\
\text { punishment }\end{array}$ & Mother's irrationality & Mother's order & $\begin{array}{c}\text { Mother's authoritarian } \\
\text { parenting subscale }\end{array}$ \\
\hline $\begin{array}{l}\text { Factor 1: Mother's verbal } \\
\text { confrontation }\end{array}$ & 1 & $.709\left(^{* *}\right)$ & $.670\left(^{* *}\right)$ & $.657\left(^{* *}\right)$ & $.844\left(^{* *}\right)$ \\
\hline $\begin{array}{c}\text { Factor 2: Mother's corporal } \\
\text { punishment }\end{array}$ & $.709\left(^{* *}\right)$ & 1 & $.834\left(^{* *}\right)$ & $.574\left(^{* *}\right)$ & $.936\left(^{* *}\right)$ \\
\hline Factor 3: Mother's irrationality & $.670\left(^{* *}\right)$ & $.834\left(^{* *}\right)$ & 1 & $.544\left(^{* *}\right)$ & $.917\left(^{* *}\right)$ \\
\hline Factor 4: Mother's order & $.657\left(^{* *}\right)$ & $.574\left(^{* *}\right)$ & $.544\left(^{* *}\right)$ & 1 & $.739\left(^{* *}\right)$ \\
\hline Mother's authoritarian parenting & $.844\left(^{* *}\right)$ & $.936\left(^{* *}\right)$ & $.917\left(^{* *}\right)$ & $\left..739^{* *}\right)$ & 1 \\
\hline
\end{tabular}

Table 6.

Correlation matrix of father's permissive parenting subscale and each factor.

\begin{tabular}{ccccc}
\hline & $\begin{array}{c}\text { Father's no } \\
\text { persistence }\end{array}$ & $\begin{array}{c}\text { Father's ignorance of } \\
\text { inappropriate behaviors }\end{array}$ & Father's lack of confidence & $\begin{array}{c}\text { Father's permissive } \\
\text { parenting subscale }\end{array}$ \\
\hline Factor 1: Father's no persistence & 1 & $.647\left(^{* *}\right)$ & $.474\left(^{* *}\right)$ & $.902\left(^{* *}\right)$ \\
$\begin{array}{c}\text { Factor 2: Father's ignorance of } \\
\text { inappropriate behaviors }\end{array}$ & $.647\left(^{* *}\right)$ & 1 & $.382\left(^{* *}\right)$ & $.830\left(^{* *}\right)$ \\
$\begin{array}{c}\text { Factor: Father's lack of confidence } \\
\text { Father's permissive parenting } \\
\text { subscale }\end{array}$ & $.474\left(^{* *}\right)$ & $.382\left(^{* *}\right)$ & 1 & $.709\left(^{* *}\right)$ \\
\hline
\end{tabular}

Table 7.

Correlation matrix of mother's permissive parenting subscale and each factor.

\begin{tabular}{ccccc}
\hline & $\begin{array}{c}\text { Mother's no } \\
\text { persistence }\end{array}$ & $\begin{array}{c}\text { Mother 's ignorance of } \\
\text { inappropriate behaviors }\end{array}$ & $\begin{array}{c}\text { Mother 's lack of } \\
\text { confidence }\end{array}$ & $\begin{array}{c}\text { Mother 's permissive } \\
\text { parenting subscale }\end{array}$ \\
\hline Factor 1: Mother's no persistence & 1 & $.644\left(^{* *}\right)$ & $.478\left(^{* *}\right)$ & $.895\left(^{* *}\right)$ \\
$\begin{array}{c}\text { Factor 2: Mother 's ignorance of } \\
\text { inappropriate behaviors }\end{array}$ & $.644\left(^{* *}\right)$ & 1 & $.400\left(^{* *}\right)$ & $.825\left(^{* *}\right)$ \\
Factor 3: Mother 's lack of confidence & $.478\left(^{* *}\right)$ & $.400\left(^{* *}\right)$ & 1 & $.732\left(^{* *}\right)$ \\
Mother 's permissive parenting subscale & $.895\left(^{* *}\right)$ & $.825\left(^{* *}\right)$ & $.732\left(^{* *}\right)$ & 1 \\
\hline
\end{tabular}

authoritarian parenting subscale and permissive parenting subscale and each factor were higher than that between two factors respectively. The correlation coefficients among each factor were between .382 and .834 , which was found to be relatively high $(p<.01)$ (see Tables 2-7).

\section{Factor Analysis}

The factor analysis is to confirm the theoretical model of scale if factors exist. Parenting Style and Dimensions Questionnaire (PSDQ) was proved to have good reliability and validity in foreign countries, namely, with mature theoretical framework, so this study only aimed to verify whether the theoretical framework was suitable for China's national conditions and cultural background and confirmatory factor analysis was used to verify the theoretical model of PSDQ. Each index of model fitting saw Table 8 .

\section{Discussions}

Children's personality formation, psychological development and social development start from the family. Under the par- ents' influence and guidance, children obtain the initial experience, knowledge, norms and habits from the family. Family is the earliest and basic educator and performer for the children. Among a lot of family factors, parenting style is the most important factor to affect the children's development, which has long been paid wide attention.

Parenting style refers to a tendency of parenting behaviors shown in the daily education and child care, which is the comprehensive reflection of the parenting concepts and behaviors and high generation of parents' various parenting behaveiors (Nadien, 1993) as well as a stable behavior style. Parenting style involves how the parents treat the children's requests and punish the children, requirement on the children's achievement as well as education of children, etc. (Taosa, 1994).

Development psychologist of American University of California Baumrind (Baumrind, 1991) $(1967,1971,1977)$ carried a study three times. She integrated two parameters: the parents' requirement and response to the children to propose three kinds of parenting style with relatively great influence: authoritative parenting, permissive parenting and authoritarian parenting. Authoritative parents think the parents should have authority in 
Table 8.

Confirmatory factor analysis of father's authoritative parenting subscale of PSDQ.

\begin{tabular}{ccccccccccc}
\hline Default Model & CMIN & DF & $P$ & CMIN/DF & NF Delta1 & RFI rho1 & IFI Delta2 & TLI rho2 & CFI & RMSEA \\
\hline $\begin{array}{c}\text { Father's authoritative parenting } \\
\text { subscale }\end{array}$ & 705.312 & 318 & .000 & 2.218 & .856 & .828 & .915 & .898 & .914 & .052 \\
$\quad \begin{array}{c}\text { Father's authoritarian } \\
\text { parenting subscale }\end{array}$ & 459.899 & 164 & .000 & 2.804 & .899 & .870 & .932 & .913 & .932 & .064 \\
$\begin{array}{c}\text { Father's permissive parenting } \\
\text { subscale }\end{array}$ & 325.773 & 87 & .000 & 3.745 & .770 & .872 & .820 & .870 & .870 & .079 \\
$\begin{array}{c}\text { Mother's authoritative } \\
\text { parenting subscale }\end{array}$ & 750.372 & 318 & .000 & 2.360 & .829 & .797 & .894 & .872 & .892 & .055 \\
$\begin{array}{c}\text { Mother's authoritarian } \\
\text { parenting subscale }\end{array}$ & 430.521 & 164 & .000 & 2.625 & .903 & .876 & .938 & .920 & .937 & .061 \\
$\begin{array}{c}\text { Mother 's permissive } \\
\text { parenting subscale }\end{array}$ & 322.371 & 87 & .000 & 3.705 & .822 & .754 & .863 & .808 & .861 & .078 \\
\hline
\end{tabular}

their own children's heart, but this authority comes from their understanding and respect to the children, frequent communication with the children, help to the children and right attitude to the children's requirements. Permissive parents give the children the biggest freedom on behavior and do not restrict the children's development. They rarely propose requirements to the children and think that the respect to the children's personal willing is the most important. And even they may leave the children alone and rarely adopt reward and punishments. Besides, they communicate with children, but the relationship is indifferent. Authoritarian parents press the children's personality and often adopt force as the means to make the children take the orders from the parents, hope the children to grow according to the parents' ideas and protect and supervise all the children's behaviors, which is a "control" and "controlled" relationship, so the child has no right to speak. If the children violate the parents' willing, they shall be punished strictly.

Parenting Style and Dimensions Questionnaire (PSDQ), with good reliability and validity, was developed based on Baumrind's theory to be widely used in the world.

This study aimed to test the reliability and validity of Chinese version of scale based on the sample of 443 students' parents in Chongqing. Reliability refers to the degree of reproducibility of test scores of the same measurement or duplicate in different time or consistency of related measurements in retest. Homogeneity reliability (Cronbach a coefficient) and test-retest reliability were used in this study to measure the stability and reliability of the scale. Generally speaking, the scale with the reliability coefficient between .7 and 1.0 is recognized to be acceptable (Gliner, Morgan, \& Harmon, 2001). However, some scholars propose stricter standard that the scale with reliability coefficient over .8 is only accepted. In this study, homogeneity reliability test results revealed that Cronbach Alpha coefficient of each subscale and factor was between .882 and .972 , which showed that the scale had relatively high homogeneity.

In order to test the time stability of the scale, 52 subjects were retested 6 weeks after the first test. Some scholars argue that in order to test test-retest reliability coefficient of single item, the coefficient is generally over .50 (Gustavsson, Bergan, Edman, Ekselius, Knorring, \& Linder, 2000). The test-retest correlation coefficient of the scale showed that test-retest reliability coefficient and test-retest reliability of each subscale and each factor were higher than .50 respectively, which was founded to be significantly correlated and revealed the scale had relatively good time stability.

Validity refers to the degree to which a scale truly tests the properties. There are various methods to verify the validity (Gotay, Blaine, Haynes, Holup, \& Pagano, 2002). Three basic validity forms were selected in this study: content validity, construct validity and confirmatory factor analysis. The content validity was measured based on the correlation coefficient between the core of each factor and the total score of the scale. Medium to high correlation coefficient between each subscale and each factor in this study was obtained to reach the significant level, which revealed that the content of each factor was consistent with the content of the questionnaire and the questionnaire had good content validity.

Construct validity refers to the degree of which a scale tests certain psychological structure or characteristics from the perspective of theory (Clark \& Watson, 1995). Correlation coefficient among factors and discriminant validity were to test the construct validity of the questionnaire.

Correlation coefficient between the score of each subscale and the total score exceeding that between subscales is a method in construct validity test in psychometrics (Huang, 2002). The study firstly investigated the internal consistency of test structure and correlation matrix between each factor and each subscale. According to the result, Pearson correlated correlations of subjects' score in each subscale and each factor were founded to be significantly related.

Confirmatory factor analysis was to confirm the theoretical model of the scale. Parenting Style and Dimensions Questionnaire (PSDQ) was approved to have mature theory frame in foreign countries, therefore, this study was only to demonstrate whether the theoretical framework was also suitable for China's national conditions and cultural background and confirmatory factor analysis was analyzed to obtain the evaluation of each fit index of fitting research mode (Hu \& Bentler, 1998; Guo, Wang, Chen, \& Han, 2007; Sivo, Fan, Witta, \& Willse, 2006).

Both Chi-square of goodness of fit test (CMIN) and degree of freedom (DF) are used to illustrate the correctness level of model, close to 2 to be acceptable. The ratios of each subscale of PSDQ are between 2.218 and 3.745. Tucker-Lewis Index (TLI): theoretically, the closer to 1 , the better the goodness of fit is, and the value over .8 illustrates the goodness of fit is ac- 
ceptable. TLIs of each subscale of PSDQ are between .808 and .920. Root mean square error of approximation (RMSEA) is used to evaluate the degree of non goodness of fit of the scale, close to 0 showing good goodness of fit, RMSEA $\leq .08$ showing reasonable goodness of fit. RMSEAs of each subscale of PSDQ are between .052 - .079. Generally, proliferation indexes (CFI: comparative fit index, NFI: non-normed fit index, IFI: incremental fit index) over .8 are acceptable. The proliferation indexs of over half of subscales of PSDQ are over .9, vast majority over .8 .

The results of confirmatory factor analysis revealed Parenting Style and Dimensions Questionnaire (PSDQ) had good construct validity and was also suitable for China's national conditions and cultural background.

In conclusion, Chinese version of Parenting Style and Dimensions Questionnaire (PSDQ) has relatively good reliability and validity and provides a relatively effective and reliable psychometric instrument for the parents to understand parenting style and dimensions and evaluate family education models.

\section{Acknowledgments}

The authors would like to show their thanks to Professor Li Tao's team of West China Hospital of Sichuan University.

\section{REFERENCES}

Baumrind, D. (1991). Effective parenting during the early adolescent transition (pp. 115-120). Hillsdale, NJ: Lawrence Erlbaum Associates, Inc.

Bi, Y, Wang, J. P., Yang, Z. H., \& Wang, Y. L. (2007). The effect of behavioral inhibition and parenting styles on adolescent's anxiety. Chinese Journal of Clinical Psychology, 15, 97-100.

Clark, L. A., \& Watson, D. (1995). Construction validity: Basic issues in objective scale development. Psychological Assessment, 3, 309319. doi:10.1037/1040-3590.7.3.309

Gliner, J. A., Morgan, G. A., \& Harmon, R. J. (2001). Measurement reliability. Journal of the American Academy of Child \& Adolescent
Psychiatry, 40, 486-488. doi:10.1097/00004583-200104000-00019

Gotay, C. C., Blaine, D., Haynes, S. N., Holup, J., \& Pagano, I. S. (2002). Assessment of quality of life in a multicultural cancer patient population. Psychological Assessment, 14, 439-450. doi:10.1037/1040-3590.14.4.439

Gustavsson, J. P., Bergan, H., Edman, G., Ekselius, L., Knorring, L. V., \& Linder, J. (2000). Swedish universities scales of personality (ssp): Construction, internal consistency and normative data. Acta Psychiatrica Scandinavica, 102, 217-225. doi:10.1034/j.1600-0447.2000.102003217.x

Guo, Q., Wang, W., Chen, X., \& Han, D. (2007). Judgment of model fitness in confirmatory factor analysis. Exploration of Psychology, 27, 83-87

Huang, G. (2002). Educational measurement and evaluation (pp. 173182). Shanghai: East China Normal University Press.

Hu, L., \& Bentler, P. M. (1998). Fit indices in covariance structure analysis: Sensitivity to under parameterized model misspecification. Psychological Methods, 3, 424-453. doi:10.1037/1082-989X.3.4.424

Nadien, M. B. (1993). Children's psychosocial development-From birth to early youth. Beijing: People's Education Press.

Robinson, C. C., Mandleco, B., \& Olsen, S. F. (2001). The parenting styles and dimension questionnaire (PSDQ). In B. F. Perlmutter, J. Touliatos, \& G. W. Holden (Eds.), Handbook of family measurement techniques: 3 (pp. 319-321). Thousand Oaks, CA: SAGE Publications, Inc.

Sivo, S. A., Fan, X., Witta, E. L., \& Willse, J. T. (2006). The search for "optima1" cutoff properties: Fit index criteria in structural equation modeling. The Journal of Experimental Education, 74, 267-288. doi:10.3200/JEXE.74.3.267-288

Taosa, L. L. (1994). 3 - 6 years old children's mother's education style and the influence factors. Psychological Development and Education, 3, 40-46.

Wang, T., \& Yuan, J. (2008). 197 college students' time management disposition and parenting styles. Chinese Mental Health Journal, 22, 429-432.

Xia, M., \& Liu, W. (2004). New research development on the interaction between children's temperament and parenting. Journal of Dalian University of Technology (Social Science Edition), 25, 65-69.

Yue, D. M., Li, M. L., Jin, K. H., \& Ding, B. K. (1993). Parenting style: Preliminary revision of EMBU and its application in neurosis patients. Chinese Mental Health Journal, 7, 97-100. 